\title{
SEMEN QUALITY CHARACTERISTICS AND PLASMA SEMINAL PROTEIN PATTERNS OF DIFFERENT EGYPTIAN RABBIT BUCKS
}

\author{
M.R. Anous ${ }^{1}$, E.B. Abdalah $^{1}$, A. Abdou ${ }^{1}$ and A.A. El-badawy ${ }^{2}$ \\ 1- Animal Production Department, Faculty of Agriculture, Ain Shams University, Shoubra El-kheima, \\ Cairo, Egypt, 2- Animal Production Research Institute, Agricultural Research Centre, Dokki, Egypt
}

\section{SUMMARY}

A total of 20 sexually mature bucks representing the Gabali ( $G A)$, Rex ( $R$ ), Californian ( $C$ ) and New Zealand White (NZW) rabbit breeds $(N=3,2,4$ and 11, respectively) and aged 9 or 12 months. They were used to study the effect of buck on some semen quality parameters and protein patterns of its seminal plasma under Egyptian conditions. The obtained results, after adjusting data for bucks age differences, indicated that semen quality characteristics of rabbit bucks represented by the reaction time (second), volume of semen per ejaculate without gel fractions $(\mathrm{ml})$, sperm-cell concentration/ejaculate/ml, percentage of sperm abnormalities, percentage of dead spermatozoa, percentage of advanced (progressive) sperm motility, mass motility grade, total sperm output, semen colour grade and semen density grade, beside the semen $\mathrm{pH}$, were not significantly different among breeds. However, age showed only a significant $(P<0.05)$ effect on the volume of the fresh ejaculate. The 4 rabbit breeds shared 2 common seminal plasma protein bands at molecular weights of 326 and 252 KDa. These 2 bands (i.e. B1 and B2) could be used as specific protein markers to characterize these 4 breeds of rabbits. Correlation values showed that both B6, B14 and may be B3 seminal plasma protein bands at molecular weights of 40, 6 and $112 \mathrm{KDa}$, respectively, can be used as specific seminal plasma protein markers to select rabbit bucks with good semen quality.

From this study, it can be concluded that SDS-PAGE of the seminal plasma protein is a sensitive method for studying the genetic structure of the population of rabbits and can be used in the selection of bucks having good semen quality. Under Egyptian conditions, semen quality of NZW bucks seems to be of lower er than those displayed by bucks of the other two imported breeds.

\section{Keywords: rabbit, bucks semen characteristics, seminal protein patterns}

\section{INTRODUCTION}

Following the appearance of avian influenza virus in many countries including Egypt and the reduction in white meat production from poultry, an opportunity has arisen for the Egyptian rabbit industry to play an important role in solving, in part, white meat shortage by overcoming the gap between animal protein demand and supply (Seleem et al., 2007). Over the last two decades some new rabbit breeds were imported into Egypt (e.g. Flanders, New Zealand White, Californian and Rex breeds) with the purpose of starting a commercial-scale rabbit production on an intensive level (Farid et al., 2000). It seems that these breeds successfully adapted to the Egyptian environmental conditions, because they are now widespread and are being reared in many rabbitries (Daader and Seleem,1999; and Enab et al., 2000).

There is some evidence that New Zealand White rabbits reared in Egypt were superior to that of other imported breeds with regards to semen quality and reproductive performance (Daader et al., 2002). However, up till now, there has been insufficient information about the overall performance potential (productive and reproductive) of the local Egyptian rabbit breed named Gabali and the other imported breeds. Thus, further investigations are required.

A great effort was performed to introduce Artificial Insemination (AI) in the Egyptian rabbit industry in both limited usage and wide scale rabbitries to gain more profits (El-Gaafary and Marai, 1994). Consequently, the reliable evaluation of both semen and the fertilizing ability of bucks are of vital importance to the success of using the AI technique. In this situation, the use of biochemical genetic techniques such as the molecular protein fingerprinting of seminal plasma may lead to obtain specific biochemical genetic markers that could be helpful in the selection of the best bucks.

The present study thus was planned to evaluate semen quality of bucks of a local Egyptian rabbit breed named Gabali and three imported rabbit breeds (i.e. Rex, Californian and New Zealand White) and comparing the protein banding patterns of their seminal plasma under Egyptian conditions. This aimed to select bucks with good semen quality, which will be used in the Egyptian rabbit industry through the use of artificial insemination.

\section{MATERIALS AND METHODS}

\section{Location:}

This work was carried out in an experimental rabbitry belonging to the Animal Production Department, Faculty of Agriculture, Ain Shams University located at Shalakan, Qalubia Governorate, Egypt during the period from 2011 to 2013 and funded by the Ain-Shams University the the research project entitled "Using some molecular genetic 
techniques in the evaluation of fertility of rabbit males".

\section{Animals and managements:}

Twenty sexually mature purebred rabbit bucks, representing the Gabali ( GA ), Rex ( R ), Californian ( C ) and New Zealand White (NZW ) breeds were used ( $\mathrm{N}=3,2,4$ and 11 , respectively). They aged 9 or 12 months and their average body weight was $3.4 \pm 0.1 \mathrm{~kg}$. All animals were healthy and clinically free of external and internal parasites. Animals were kept under the same managerial, hygienic and environmental conditions and were housed individually in flat deck cages in a windowed rabbitry with natural ventilation. They were fed a commercial concentrate pelleted diet $(18 \%$ crude protein and $2600 \mathrm{kcal} / \mathrm{kg}$ ) twice a day according to NRC (1994) recommendations. Fresh tap water was automatically provided ad libitum via stainless steel nipples located inside each cage.

\section{Collection of semen samples:}

Libido (i.e. sexual desire) was measured in terms of reaction time (in seconds) and was estimated from the time the doe was placed inside the buck's cage up to the point when the buck started to mount the doe (Daader et al., 1999).

The fresh semen sample was artificially collected early in the morning from each buck twice a week using an artificial vagina (AV) with an inside temperature of $38^{\circ} \mathrm{C}$ as described by El-Sherbiny (1987) and Tharwat (1990). A graduated collection tube was fixed at one side of the inner-liner. All males were trained to ejaculate into an AV for four weeks before semen collection. Two female rabbits were used as a teaser leaved on top of the buck's cage for several minutes. Male was allowed to false mounts three time as this increased sperm concentration by rate $40 \%$ (Seed et al., 1996), then holding a teaser female rabbit by a hand, and the prepared AV was maintained by the other hand underneath the female in the inguinal area; such a position gives the possibility for the male to ejaculate semen into AV. Immediately after semen collection, gel plugs were removed using pasture pipettes and a gift. The volume of the fresh ejaculate without gel fractions ( in $\mathrm{ml}$ ) for each ram was recorded using a graduated semen conical tube. Then, semen samples were immediately transferred to the laboratory and were placed in a $37^{\circ} \mathrm{C}$ water bath, then evaluated. After each collection all the equipment were washed using tap water, soap solution, glass bi-distilled water, ethanol $70 \%$, respectively.

\section{Semen evaluation:}

In fresh ejaculates, count of total sperm output was measured. Also, $\mathrm{pH}$ was measured using a $\mathrm{pH}$ paper, which ranged from $4.5-7.5$. The semen colour per buck was visually assessed and graded from one to three scores, which ranged from white to yellow. The semen density was estimated by gently tilted the semen collecting tube and straightly returned and the semen movement during that was observed, then was graded from 0 to 5 scores. For the determination of mass motility of semen, a drop of fresh semen was placed on a clean warmed microscopic slide $\left(37^{\circ} \mathrm{c}\right)$ without a cover slip. The wave motion was observed with low power lens (10x), and was graded from 0 to 5 scores (from total immobility to rapid wave motion) according to Chemineau et al. (1991). For the determination of sperm progressive (advanced) motility (\%), the percentage of motile spermatozoa was measured according to Seleem (2005) by placing a small drop of semen on a clean warmed microscope slide, and then diluted with drops of a $2.9 \%$ of sodium citrate solution ( a dissolve $2.9 \mathrm{~g}$ of sodium citrate in a $100 \mathrm{ml}$ of sterile distilled water). Then they carefully mixed together and covered with a warmed cover slip. Assessments were made with high power lens (40x) using a scale graded from 0 to 5 scores (from no displacement of sperm cells to straight and rapid displacement of spermatozoa) according to Chemineau et al. (1991). The sperm-cell concentration per ejaculate was calculated with the aid of a haemocytometer according to Loskutoff and Crichton (2001). The number of sperms per millimeter was calculated as follows:

Concentration $/ \mathrm{ml}=($ Dilution Factor $=200) \times($ Count in the five squares $) \times\left(0.05 \times 10^{6}\right)$. Sperm abnormalities (\%) were estimated using a magnification of $500 \times$ with a differential interference contrast microscope. Abnormalities can occur in the head, neck, mid-piece, tail, or any combination of these parts of the sperm cell (Salisbury et al., 1978). Non-vital sperms were calculated as dead spermatozoa (\%). The recorded number of stained dead sperms could be determined the percentage of dead spermatozoa (Evan and Maxwell, 1987). Acrosomal damages (\%) or percentages of unreacted acrosom of spermatozoa with an abnormal apical ridge was determined using a Giemsa stain procedure as described by Watson (1975).

\section{Seminal plasma protein electrophoresis:}

Seminal plasma was obtained by centrifugation semen samples at $10000 \mathrm{rpm}$ for 10 minutes at $4^{\circ} \mathrm{C}$ and the plasma protein was transferred to clean plastic vials and stored at $-20^{\circ} \mathrm{C}$ until the protein electrophoretic analysis. Protein samples were applied to SDS-PAGE electrophoresis technique as described previously for blood plasma proteins by Laemmli (1970). Seminal plasma protein fractionations was performed exclusively on vertical slab $(19.8 \mathrm{~cm} \times 26.8 \mathrm{~cm} \times 0.2 \mathrm{~cm}) \quad 15 \%$ polyacrylamid gel using the electrophoresis apparatus manufactured by Aplex. Then, the obtained polyacrylamid gels were photographed and analyzed.

\section{Gels and Densitometric analysis:}

All resulted gels from the protein electrophoresis of seminal plasma were analyzed using Gel Analyzer ver. 3 and SPSS 15 software (2004). The profiles 
were scored as a binary data ( 1 if band present and 0 if it absent). This data was introduced to the SPSS software package in order to infer similarity indexes matrix for both within and among the four studied breeds according to Bardacki and Skibinski (1994). The similarity index between any two individuals of each breed was calculated using the formula:

\section{Where:}

$$
S_{x y}=2 n_{x y} /\left(n_{x}+n_{y}\right)
$$

$\mathbf{n}_{\mathbf{x y}}$ : The number of bands shared by $\mathbf{x}$ and $\mathbf{y}$ individuals.

$\mathbf{n}_{\mathbf{x}}$ and $\mathbf{n}_{\mathbf{y}}$ : The number of bands scored for each individual.

$\mathbf{S}_{\mathbf{x y}}$ : The similarity value between $\mathbf{x}$ and $\mathbf{y}$ individuals.

\section{Dendrogram Construction:}

For constructing a dendrogram dealing with the phylogenetic relationships among the individuals of the four studied breeds, the data generated from all protein analyses (i.e. protein banding patterns) were introduced to SPSS software using the binary values $(1,0)$. Then, the dendrogram was constructed according to Sneath and Sokal (1973), using the Unweighted Pair-Group Method of Analysis (UPGMA).

\section{Statistical analysis:}

Semen data statistical analysis was performed using SAS software (2004). Analysis of variance (ANOVA) was used after adjusting the data for bucks age differences. Then, Duncan's multiple range test (Duncan, 1955) was used for separating the difference among the means at a significance level of $\mathrm{P}<0.05$. The phenotypic correlation coefficients between each characteristics of seminal plasma and protein banding patterns were also calculated and tested for significance according to Snedecor and Cochran (1967).

\section{RESULTS AND DISCUSSION}

\section{The physical quality of semen:}

Results in Table 1 showed that semen physical traits considered in the present study, which reflect the quality of semen produced by bucks of the 4 breeds, are generally highly variable in terms of $\mathrm{CV} \%$ and ranged from 3.04 for the fresh ejaculate $\mathrm{pH}$ to 72.90 for the reaction time. The highest variability was related to libido of bucks, livability of sperms and number of spermatozoa. However, traits representing sperm motility seemed to be less variable. This may be related to using bucks with different ages and breeds, and also due to the small numbers of bucks used for certain breeds (i.e. only 2 and 3 animals in the case of Rex and Gabali breeds, respectively). On the other hand, it well known that the NZW rabbit breed reared now in Egypt is less homogeneous compared to the existed other pure breeds, which may also explains the high variability of most of the studied traits.

The results of the analysis of variance reported in Table 2 indicated that breed had no significant effect on all considered semen characteristics of rabbit bucks. However, age showed only a significant $(\mathrm{P}<0.05)$ effect on the volume of the fresh ejaculate. These results give justification for grouping individuals of the 4 breeds to examine the protein banding patterns of their seminal plasma under the environmental Egyptian conditions.

Rex and Californian rabbit bucks seemed to perform better $(\mathrm{P}>0.05)$ than New Zealand White and Gabali bucks in terms of semen quality characteristics (Table 3). This was represented by the reaction time (second), ejaculate volume without gel fractions $(\mathrm{ml})$, dead spermatozoa $\%$ and sperm abnormalities \%. The Californian breed exceeded $(\mathrm{P}>0.05)$ all the other breeds in semen density grade, count (or total sperm output) and sperm concentration/ejaculate/ml. However, the worst in these traits was the Gabali breed. The Rex breed exceeded $(\mathrm{P}>0.05)$ all the other breeds in mass motility grade and progressive motility $\%$. However the worst in these traits was the New Zealand Whit breed. The Gabali breed had the smallest ejaculate volume, count and concentration and the New Zealand White breed was the highest in sperm abnormalities and dead spermatozoa compared with the other breeds (Table 3 ). The big values of means standard errors obtained especially for Rex and Gabali breeds may be explained by the small number of individuals representing these two breeds.

These results are comparable with those obtained by Meshreky et al. (2005) who compared Red Baladi and V-line (line selected on the basis of litter size at weaning) rabbit bucks. Also, elsewhere similar values for the overall mean volume of ejaculate were reported (Vicente et al., 2000) in R-line rabbits (line selected on the basis of growth rate from weaning to slaughter; 28-63 days of age) and also for sperm abnormalities (García-Tomás et al., 2006) in two rabbit sire lines and their reciprocal crosses. However, values for sperm-cell concentration and motility were higher than those reported by the same authors. On the other hand, values reported for the New Zealand White breed in the present study were smaller than those reported by Daader et al. (2002) and Safaa et al. (2008). These differences could be explained not only by genetic and environmental factors, but also by the different criteria employed for the evaluation and the use of various semen processing technologies. In male rabbits of Algerian population, Boulbina et al. (2012) underlined the important effect of birth season on semen quality characteristics.

On the other hand, reaction time, physical and biochemical semen characteristics of four breeds of rabbits (Calilfornian (Cal), New Zealand White $(\mathrm{NZW})$, Sinai (Sin) and Balady (Bal) were studied 
by Abd El-Azim and El-Kamash (2011). They concluded that the effect of breed on semen quality characters was highly significant and that all the semen biochemical characters were higher in Bal and Sin when compared with Cal and/or NZW rabbits. To investigate the effect of age, breed, sire and generation on body weight and ejaculate characteristics of rabbit bucks of three breeds (New-
Zealand White, Chinchilla and Californian White), Akpa et al. (2012) reported that the ejaculate characteristics of the rabbit bucks were influenced by age, breed and sire. The values obtained were within the normal standards for rabbits-bucks. New Zealand White bucks proved superior in terms of ejaculate characteristics.

Table 1. Number of recorded animals (N), overall means, standard deviations (SD) and coefficients of variation (CV\%) for semen quality characteristics of rabbit bucks

\begin{tabular}{llrrr}
\hline Semen Characteristics & N & Mean & \multicolumn{1}{c}{ SD } & CV\% \\
\hline Reaction time (second) & 20 & 29.70 & 21.65 & 72.90 \\
Ejaculate volume (ml) & 20 & 0.67 & 0.28 & 41.79 \\
pH & 19 & 6.91 & 0.21 & 03.04 \\
Mass motility grade & 20 & 4.30 & 0.66 & 15.35 \\
Progressive motility \% & 20 & 87.25 & 7.63 & 08.74 \\
Colour grade & 20 & 1.05 & 0.22 & 20.95 \\
Density grade & 20 & 1.40 & 0.68 & 48.57 \\
Dead \% & 19 & 6.11 & 4.11 & 67.27 \\
Abnormality \% & 19 & 7.32 & 4.52 & 61.75 \\
Count & 20 & 42.50 & 27.85 & 65.53 \\
Concentration (million/ml) & 20 & 425.00 & 278.50 & 65.53 \\
\hline
\end{tabular}

Table 2. Analysis of variance (mean squares ${ }^{\mathrm{T}}$ ) for the effects of breed and age on semen quality characteristics of rabbit bucks

\begin{tabular}{|c|c|c|c|c|c|c|}
\hline \multirow[t]{2}{*}{ Semen Characteristics } & \multicolumn{2}{|c|}{ Mean squares } & \multicolumn{2}{|c|}{ F Value } & \multicolumn{2}{|c|}{ Significance } \\
\hline & Breed & Age & Breed & Age & Breed & Age \\
\hline Reaction time (second) & 772.5792 & 47.9913 & 1.77 & 0.11 & NS & $\mathrm{NS}$ \\
\hline Ejaculate volume (ml) & 0.0634 & 0.3110 & 0.93 & 4.57 & NS & $*$ \\
\hline $\mathrm{pH}$ & 0.0154 & 0.0343 & 0.31 & 0.69 & NS & NS \\
\hline Mass motility grade & 0.6247 & 0.3194 & 1.56 & 0.80 & NS & NS \\
\hline Progressive motility $\%$ & 39.8409 & 0.0166 & 0.61 & 0.01 & NS & NS \\
\hline Colour grade & 0.0136 & 0.0056 & 0.23 & 0.09 & NS & NS \\
\hline Density grade & 0.4005 & 0.8283 & 0.89 & 1.84 & NS & NS \\
\hline Dead $\%$ & 3.9096 & 14.7974 & 0.20 & 0.75 & NS & NS \\
\hline Abnormality $\%$ & 7.9088 & 70.6880 & 0.40 & 3.62 & NS & NS \\
\hline Count & 712.6000 & 33.4000 & 0.85 & 0.04 & NS & NS \\
\hline Concentration (million/ml) & 71259.60 & 3341.500 & 0.85 & 0.04 & NS & NS \\
\hline
\end{tabular}

Table 3. Least squares Means \pm SE for the effect of breed on semen quality characteristics of rabbit bucks ${ }^{\mathrm{T}}$

\begin{tabular}{lcccc}
\hline \multicolumn{1}{c}{ Semen Characteristics } & New Zealand & \multicolumn{2}{c}{ Breeds } \\
& White & Californian & Rex & Gabali \\
\hline Reaction time (second) & $38.64 \pm 6.52$ & $15.25 \pm 10.80$ & $12.50 \pm 15.35$ & $27.6 \pm 12.51$ \\
Ejaculate volume (ml) & $0.64 \pm 0.10$ & $0.79 \pm 0.10$ & $0.79 \pm 0.20$ & $0.55 \pm 0.20$ \\
pH & $6.96 \pm 0.10$ & $6.90 \pm 0.11$ & $6.78 \pm 0.20$ & $6.84 \pm 0.12$ \\
Mass motility grade & $4.06 \pm 0.20$ & $4.26 \pm 0.31$ & $5.06 \pm 0.50$ & $4.75 \pm 0.40$ \\
Progressive motility \% & $85.55 \pm 2.50$ & $87.50 \pm 4.10$ & $93.49 \pm 5.80$ & $88.98 \pm 4.80$ \\
Colour grade & $1.10 \pm 0.10$ & $1.00 \pm 0.11$ & $0.99 \pm 0.20$ & $0.99 \pm 0.20$ \\
Density grade & $1.33 \pm 0.20$ & $1.74 \pm 0.30$ & $0.91 \pm 0.50$ & $1.53 \pm 0.40$ \\
Dead \% & $6.86 \pm 1.39$ & $5.31 \pm 2.60$ & $3.64 \pm 3.20$ & $5.79 \pm 2.70$ \\
Abnormality \% & $8.32 \pm 1.40$ & $5.88 \pm 2.60$ & $3.71 \pm 3.20$ & $7.47 \pm 2.60$ \\
Count & $47.00 \pm 8.90$ & $48.0 \pm 14.50$ & $41.59 \pm 20.70$ & $19.19 \pm 17.30$ \\
Concentration (million/ml) & $469.97 \pm 89$ & $480.66 \pm 145$ & $415.95 \pm 207$ & $191.92 \pm 173$ \\
\hline
\end{tabular}

$\mathrm{T}$ : Means in all lines are not significantly different $(\mathrm{P}>0.05)$.

\section{Biochemical genetic fingerprinting:}

In the present study, Polyacrylamide gel electrophoresis (PAGE) for the seminal plasma protein was used to assess structure of individuals of the 4 rabbit breeds and to compare among these breeds at the SDS-protein level. Figure 1 and Table 4 showed electrophoretic seminal plasma protein banding patterns of 15 individuals from a total of 20 
individuals, where the other five animals were sold before taking the samples $(\mathrm{N}=5)$. The total number of bands recorded for this population of animals was 14 bands with molecular weights ranging from 326 to 6 $\mathrm{KDa}$ and band relative fronts ranged from 0.06 to 0.83 . The 4 rabbit breeds shared 2 common bands at molecular weights of 326 and $252 \mathrm{KDa}$. These 2 bands (i.e. B1 and B2) could be used as specific protein markers to characterize these 4 breeds of rabbits. These results need confirmation using more individuals for Rex and Gabali breeds.

According to protein polymorphism data, the NZW rabbit showed 2 monomorphic bands with molecular weights of 326 and $252 \mathrm{KDa}$, while the other bands were polymorphic with molecular weights ranging from 112 to $6 \mathrm{KDa}$. This means that there are high individual variations within the population representing this breed of rabbits. On the contrary, the other 3 breeds of rabbits showed an unique banding pattern with only monomorphic bands indicating a high homogeneity that may be explained by the small number of individuals representing each breed.

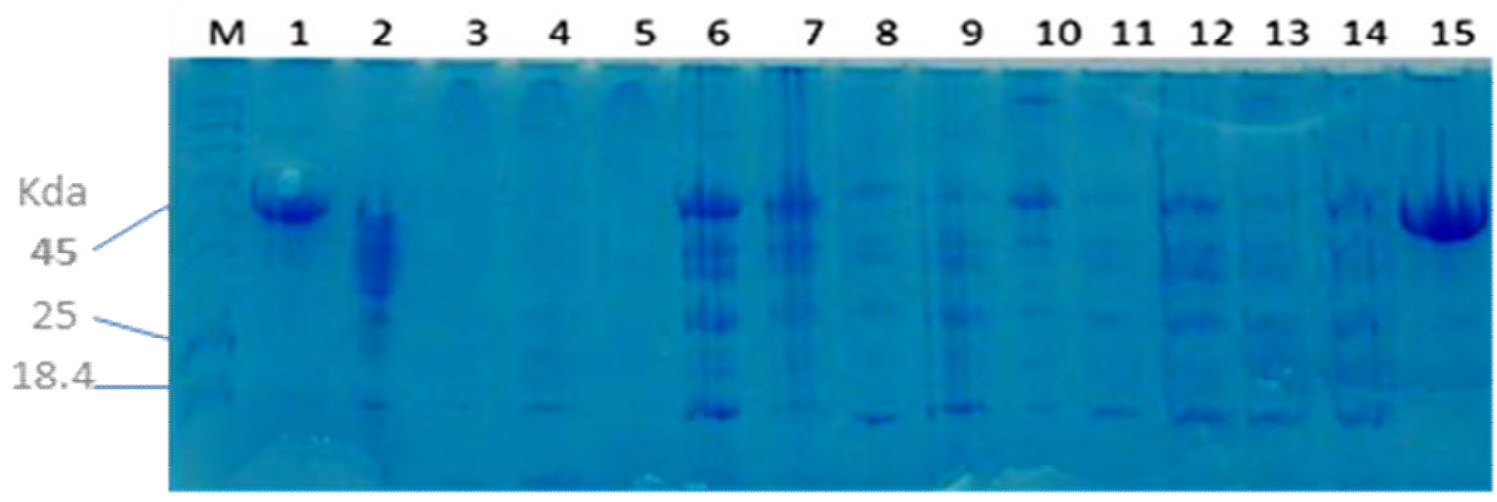

Figure 1. Seminal plasma protein electrophoretic banding patterns for studied rabbit breeds

Table 4. SDS-PAGE of seminal plasma protein polymorphism within the studied rabbit population ${ }^{\neq}$

\begin{tabular}{cccccccccccccccccc}
\hline $\mathbf{R F}^{\dagger}$ & $\begin{array}{c}\mathbf{M W}^{*} \\
(\mathbf{K D a})\end{array}$ & $\mathbf{M}^{\Delta}$ & $\mathbf{1}$ & $\mathbf{2}$ & $\mathbf{3}$ & $\mathbf{4}$ & $\mathbf{5}$ & $\mathbf{6}$ & $\mathbf{7}$ & $\mathbf{8}$ & $\mathbf{9}$ & $\mathbf{1 0}$ & $\mathbf{1 1}$ & $\mathbf{1 2}$ & $\mathbf{1 3}$ & $\mathbf{1 4}$ & $\mathbf{1 5}$ \\
\hline 0.06 & 326 & 0 & 1 & 1 & 1 & 1 & 1 & 1 & 1 & 1 & 1 & 1 & 1 & 1 & 1 & 1 & 1 \\
0.11 & 252 & 0 & 1 & 1 & 1 & 1 & 1 & 1 & 1 & 1 & 1 & 1 & 1 & 1 & 1 & 1 & 1 \\
0.27 & 112 & 1 & 1 & 0 & 0 & 0 & 0 & 1 & 1 & 1 & 1 & 1 & 1 & 1 & 1 & 1 & 1 \\
0.33 & 82 & 1 & 1 & 0 & 0 & 0 & 0 & 0 & 0 & 0 & 0 & 0 & 0 & 0 & 0 & 0 & 0 \\
0.35 & 74 & 0 & 0 & 1 & 0 & 0 & 0 & 1 & 1 & 1 & 1 & 1 & 1 & 1 & 1 & 1 & 1 \\
0.47 & 40 & 0 & 1 & 0 & 0 & 1 & 0 & 1 & 1 & 1 & 1 & 1 & 1 & 1 & 1 & 1 & 1 \\
0.50 & 35 & 1 & 1 & 0 & 0 & 0 & 0 & 0 & 0 & 0 & 0 & 0 & 0 & 0 & 0 & 0 & 0 \\
0.55 & 27 & 0 & 0 & 1 & 0 & 1 & 0 & 1 & 1 & 1 & 1 & 1 & 1 & 1 & 1 & 1 & 1 \\
0.58 & 23 & 1 & 1 & 0 & 0 & 0 & 0 & 0 & 0 & 0 & 0 & 0 & 0 & 0 & 0 & 0 & 0 \\
0.63 & 18 & 0 & 0 & 1 & 0 & 1 & 0 & 1 & 1 & 1 & 1 & 1 & 1 & 1 & 1 & 1 & 1 \\
0.76 & 9 & 0 & 1 & 0 & 1 & 1 & 0 & 0 & 0 & 0 & 0 & 0 & 0 & 0 & 0 & 0 & 0 \\
0.81 & 7 & 0 & 0 & 0 & 0 & 0 & 0 & 1 & 0 & 0 & 0 & 0 & 0 & 0 & 0 & 0 & 0 \\
0.82 & 7 & 0 & 0 & 0 & 0 & 1 & 1 & 0 & 0 & 0 & 0 & 0 & 0 & 0 & 0 & 0 & 0 \\
0.83 & 6 & 0 & 0 & 1 & 1 & 0 & 0 & 0 & 0 & 0 & 0 & 0 & 0 & 0 & 0 & 0 & 0 \\
\hline
\end{tabular}

${ }^{\neq}$: Samples from 1-10 represent New Zealand White breed; Samples 11 and 12 represent Californian breed; Sample 13 represents Gabali breed; amples 14 and 15 represent Rex breed. $0=$ absent and $1=$ present.

: Relative front of bands from 1 (B1) to 14 (B14), respectively;

*: Molecular weight; ${ }^{\Delta}$ : Protein marker.

The dendrogram of this population of rabbits (Figure 2) showed that it was divided into two groups; the first representing the New Zealand White breed $(\mathrm{N}=10)$ and the second represented the other 3 breeds $(\mathrm{N}=5)$. The first group was also divided into 2 sub-groups, which reflect the existed variability within this breed. However, the individuals of the second group were dispersed without clear trend, which may confirm their common protein banding patterns. 


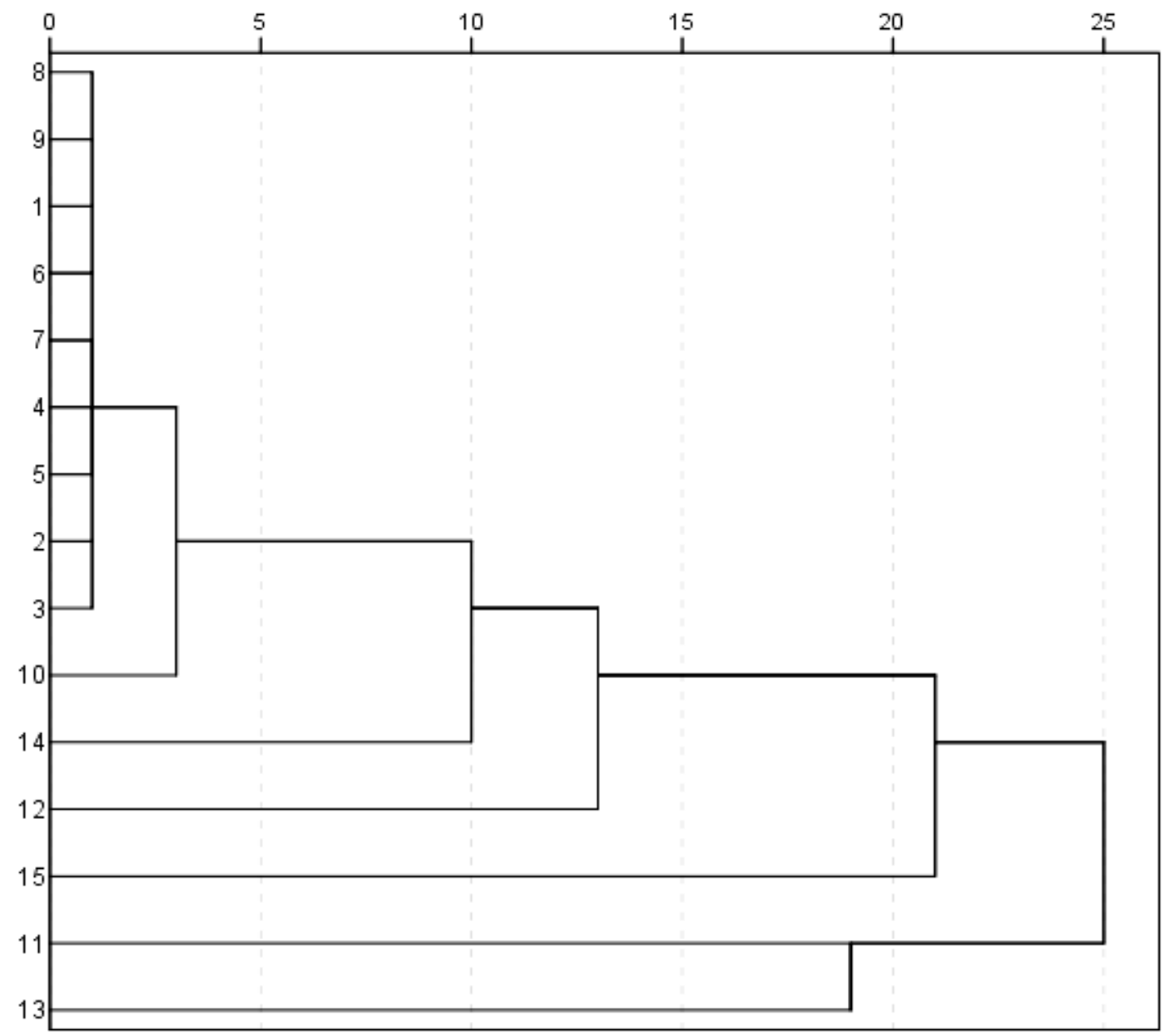

Figure 2. Dendrogram of genetic relationship among rabbit bucks

\section{Relationships between semen traits and protein banding patterns:}

The phenotypic correlation coefficients between semen characteristics and protein banding patterns (Table 5) revealed that ejaculate volume $(\mathrm{ml})$ had positively significant $(\mathrm{P}<0.05) \quad$ phenotypic correlations with $\mathrm{B} 8$ and $\mathrm{B} 10$ and negatively significant $(\mathrm{P}<0.05)$ phenotypic correlations with $\mathrm{B} 4$, B7 and B9. Positively significant $(\mathrm{P}<0.05)$ phenotypic correlations were also observed between $\mathrm{pH}$ and each of B4, B7 and B9. Both mass motility grade and progressive motility $\%$ had positively significant $(\mathrm{P}<0.05)$ phenotypic correlations with $\mathrm{B} 3$ and B6 and negatively significant $(\mathrm{P}<0.05)$ phenotypic correlations with B14. Colour grade and density grade both had significant $(\mathrm{P}<0.05)$ positive phenotypic correlation with $\mathrm{B} 14$ and significant $(\mathrm{P}<0.05)$ negative phenotypic correlation with B6. Reaction time, dead $\%$, abnormality $\%$, count and concentration (million $/ \mathrm{ml}$ ) both showed nonsignificant phenotypic correlations with all bands. On the other hand, both B1 and B2 presented zero correlation coefficients with all the studied traits, thus they were removed from Table 5. Correlation values presented in Table 5 showed also that both B6 and B14 appeared to be more important than the other seminal plasma protein bands in the separation among rabbit bucks concerning their semen quality (followed by B3). Thus, these two seminal plasma protein bands at molecular weights of 40 and $6 \mathrm{KDa}$, respectively, and may be $\mathrm{B} 3$ at molecular weight of $112 \mathrm{KDa}$, can be used as specific seminal plasma protein markers to select rabbit bucks with good semen quality, which will be used in the rabbit industry through breeding programs and Artificial Insemination.

From this study, it can be concluded that SDSPAGE of the seminal plasma protein is a sensitive method for studying the genetic structure of the population of rabbits and can be used in the selection of bucks having good semen quality. We may need to increase sample size and also to apply SDS-PAGE technique on blood samples taken from the same individuals to confirm our results. We also concluded that, under Egyptian conditions, semen quality of NZW bucks seems to be less better than those displayed by bucks of the other two imported breeds. 
Table 5. Correlations ${ }^{\$}$ between semen characteristics and seminal protein banding patterns

\begin{tabular}{|c|c|c|c|c|c|c|c|c|c|c|c|c|}
\hline \multirow[t]{2}{*}{ Traits } & \multicolumn{12}{|c|}{ Bands } \\
\hline & B3 & B4 & B5 & B6 & B7 & B8 & B9 & B10 & B11 & $\mathrm{B} 12$ & B13 & B14 \\
\hline Reaction time (second) & -0.062 & 0.168 & 0.380 & $\begin{array}{l}- \\
0.070\end{array}$ & 0.168 & 0.003 & 0.168 & 0.003 & 0.124 & $\begin{array}{l}- \\
0.107\end{array}$ & $\begin{array}{l}- \\
0.126\end{array}$ & 0.206 \\
\hline Ejaculate volume $\left(\mathrm{cm}^{3}\right)$ & 0.456 & $-\overline{0.503}$ & -0.147 & 0.395 & $-\overline{0.503}$ & 0.578 & $-\overline{0.503}$ & 0.578 & $\begin{array}{l}- \\
0.498\end{array}$ & $\begin{array}{l}- \\
0.177\end{array}$ & $\begin{array}{l}- \\
0.337\end{array}$ & $\begin{array}{l}- \\
0.257\end{array}$ \\
\hline $\mathrm{pH}$ & -0.147 & 0.517 & -0.147 & $\begin{array}{l}- \\
0.122\end{array}$ & 0.517 & $\begin{array}{l}- \\
0.095\end{array}$ & 0.517 & $\begin{array}{l}- \\
0.095\end{array}$ & 0.428 & 0.095 & $\begin{array}{l}- \\
0.238\end{array}$ & 0.428 \\
\hline Mass motility & 0.680 & 0.288 & 0.237 & 0.586 & 0.288 & $\begin{array}{l}- \\
0.135\end{array}$ & 0.288 & $\begin{array}{l}- \\
0.135\end{array}$ & 0.134 & 0.134 & $\begin{array}{l}- \\
0.154\end{array}$ & $\begin{array}{l}- \\
0.731\end{array}$ \\
\hline Progressive motility $\%$ & 0.608 & 0.098 & 0.240 & 0.632 & 0.098 & $\begin{array}{l}- \\
0.024\end{array}$ & 0.098 & $\begin{array}{l}- \\
0.024\end{array}$ & 0.024 & 0.144 & $-\overline{0.096}$ & $\begin{array}{l}- \\
0.695\end{array}$ \\
\hline Colour & -0.443 & $\begin{array}{l}- \\
0.071\end{array}$ & 0.161 & $\begin{array}{l}- \\
0.535\end{array}$ & $\begin{array}{l}- \\
0.071\end{array}$ & 0.105 & $\begin{array}{l}- \\
0.071\end{array}$ & 0.105 & $\begin{array}{l}- \\
0.105\end{array}$ & $\begin{array}{l}- \\
0.105\end{array}$ & $\begin{array}{l}- \\
0.105\end{array}$ & 0.681 \\
\hline Density & -0.452 & $\begin{array}{l}- \\
0.134\end{array}$ & -0.075 & $\begin{array}{l}- \\
0.583\end{array}$ & $\begin{array}{l}- \\
0.134\end{array}$ & 0.196 & $\begin{array}{l}- \\
0.134\end{array}$ & 0.196 & $\begin{array}{l}- \\
0.196\end{array}$ & $\begin{array}{l}- \\
0.196\end{array}$ & $\begin{array}{l}- \\
0.196\end{array}$ & 0.784 \\
\hline Dead \% & -0.377 & $\begin{array}{l}- \\
0.136\end{array}$ & 0.057 & $\begin{array}{l}- \\
0.222\end{array}$ & $\begin{array}{l}- \\
0.136\end{array}$ & 0.293 & $\begin{array}{l}- \\
0.136\end{array}$ & 0.293 & 0.127 & 0.080 & 0.033 & 0.453 \\
\hline Abnormality \% & 0.074 & $\begin{array}{l}- \\
0.232\end{array}$ & 0.237 & 0.150 & $\begin{array}{l}- \\
0.232\end{array}$ & 0.258 & $\begin{array}{l}- \\
0.232\end{array}$ & 0.258 & $\begin{array}{l}- \\
0.090\end{array}$ & 0.078 & $\begin{array}{l}- \\
0.006\end{array}$ & $\begin{array}{l}- \\
0.090\end{array}$ \\
\hline Count & -0.033 & $\begin{array}{l}- \\
0.111\end{array}$ & -0.160 & $\begin{array}{l}- \\
0.038\end{array}$ & $\begin{array}{l}- \\
0.111\end{array}$ & $\begin{array}{l}- \\
0.335\end{array}$ & $\begin{array}{l}- \\
0.111\end{array}$ & $\begin{array}{l}- \\
0.335\end{array}$ & $\begin{array}{l}- \\
0.083\end{array}$ & 0.277 & 0.414 & $\begin{array}{l}- \\
0.372\end{array}$ \\
\hline Concentration(million/ml) & -0.033 & $\begin{array}{l}- \\
0.111\end{array}$ & -0.160 & $\begin{array}{l}- \\
0.038\end{array}$ & $\begin{array}{l}- \\
0.111\end{array}$ & $\begin{array}{l}- \\
0.335\end{array}$ & $\begin{array}{l}- \\
0.111\end{array}$ & $-\overline{0.335}$ & $\begin{array}{l}- \\
0.083\end{array}$ & 0.277 & 0.414 & $\begin{array}{l}- \\
0.372\end{array}$ \\
\hline
\end{tabular}

$\$$ : Values of correlation coefficients greater than 0.50 are significant at $\mathrm{P}<0.05$.

\section{ACKNOWLEDGEMENT}

The authors are very grateful to the president of Ain-Shams University who funded this study through the research project entitled "Using some molecular genetic techniques in the evaluation of fertility of rabbit males". The authors also are indebted to $\mathrm{Mr}$. Ahmed Said Baky, Assistant Lecturer at the Department of Animal Production, Faculty of Agriculture, Ain Shams University, Cairo, Egypt for his help during the collection of semen samples.

\section{REFERENCES}

Abd El-Azim, A. and E. M. El-Kamash, 2011. "Evaluation of semen quality and its relation to mating system for some breeds of rabbits under environmental conditions in the middle of Egypt." Egypt. Poult. Sci. 31(II): 467-480.

Akpa, G. N., H. K. Yahaya and U. C. Martin, 2012. "The effects of age, breed, sire, body weight and the ejaculate characteristics of rabbit bucks." Intern. J. of Anim. and Vet. Advances 4(3): 191194.

Bardacki, F. and D.O.F. Skibinski, 1994. Application of the RAPD technique in tilapia fish: species and subspecies identification. Heredity, 73: 123-177.

Boulbina, I., H. Ain-Baziz, I. Ilès, S. Zenia, R. Belabbas and S. Temim, 2012. "Effect of birth season on onset of puberty and semen characteristics in male rabbit of algerian population (oryctolagus cuniculus)." Proceedings 10th World Rabbit Congress Sharm El- Sheikh Egypt, p 335-339.

Chemineau, P., Y. Cagnie, Y. Gue'rin, P. Orgeur and J.C. Vallet, 1991. Training Manual on Artificial Insemination in Sheep and Goat. FAO, Rome.
Daader A.H., T.S.T. Seleem, 1999. Recent trends in rabbit production. In Proc: 1st Inter. Conf. on Indigenous Versus Acclimatized Rabbits. 7-9 Sept., El-Arish, North-Sinai, Egypt, 23-50.

Daader A.H., H.A. Gabr, T.S.T. Seleem, 1999. Productive and reproductive performance of New-Zealand White and Californian rabbit bucks as affected by supplementing natural clay to the diet during summer and winter seasons. In Proc: 7th Sci., Conf. on Anim. Nutr. 19-21 Oct., ElArish, North Sinai, Egypt, 565-579.

Daader A.H., H.A. Gabr, A.M.F. Khadr, T.S.T. Seleem, 2002. Fertility traits in different breeds in rabbit does as affected by coitus frequency and remating interval. In Proc: 3rd Sci. Conf. on Rabb. Prod. in Hot Climates. 8-11 Oct., Hurghada, Egypt, 253 - 262.

Duncan D.B. 1955. Multiple range and multiple (Ftest). Biometrics, 11, 1-42.

El-Gaafary M.N. and I.F.M. Marai, 1994. Artificial insemination in rabbits. In Proc: 1st Inter. Conf. on Rabb. Prod. in Hot Climate. 6-8 Sept., Cairo, Egypt, 95-110.

El-Sherbiny, A. 1987. "Seasonal variation in seminal characteristics of rabbits." M. Sc. Thesis, Fac. of Agric., Ain-Shams Univ., Cairo,Egypt.

Enab A.A., A.A. Hekil, F.H. Abdou, 2000. Analysis of a selection experiment for some economic traits in rabbits. Egyptian Journal of Rabbit Sci., 10, 2, 341-353.

Evans, G. and W.M.C. Maxwell, 1987. Salamon's artificial insemination of sheep and goats. Sydney. Buttetworths.

Farid A., E.A. Afifi, M.H. Khalil, H.A. Gad, 2000. Estimation of doe breeding values of three standard breeds of rabbits raised under commercial intensive system of production in 
Egypt. Egyptian Journal of Rabbit Sci., 10, 2, 307-325.

García-Tomás M., J. Sánchez, O. Rafel, J. Ramon, M. Piles, 2006. Variability, repeatability and phenotypic relationships of several characteristics of production and semen quality in rabbit. Animal Reproduction Sci., 93, 88-100.

Laemmli, U. K., 1970. Cleavage structural protein during the assembly of the head of bactriophage T4. Nature, 227, 680-685.

Loskutoff, N.M. and E.G. Crichton, 2001. Standard operating procedures for genome resource banking. Center for conservation and research, Omaha's Henry Doorly Zoo, Omaha. pp. 1-16.

Meshreky S.Z., S.A. Gad Alla, M.M. Arafa, 2005. Growth performance, carcass traits, physiological response and economical efficiency of Baladi Red, V-Line rabbits and their cross under Egyptian environmental conditions. In Proc: The 4th Inter. Con. on Rabbit Prod. in Hot Clim., Sharm El-Sheikh, Egypt,197-210.

NRC, 1994. Nutrient Requirement of Rabbits. National Academy of Science, Washington, DC. USA.

Safaa, H. M., M. E. Emarah, N. F. A. Saleh, 2008. "Seasonal effects on semen quality in black baladi and White New Zealand rabbit bucks." World Rabbit Sci. 16: 13-20.

Salisbury G.W., L. Van Demark, JR. Lodge, 1978. Extenders and extension of unfrozen semen. In: Physiology of reproduction and artificial insemination in cattle. San Francisco: W. H. Freeman and Co, 1978:442-493.

SAS, 2004. SAS /STAT User's Guide (Version 9.1). SAS Inst. Inc., Cary.

Seed, J., R. E. Chapin, E. D. Clegg, L. A. Dostal, R. H. Foote, M. E. Hurtt, G. R. Klinefelter, S. L.
Makris, S. D. Perreault, S. Schrader, D. Eyler, R. Sprando, K. A. Treinen, D. N. R. Veeramachaneni, D. L. Wise, 1996. "Methods for assessing sperm motility, morphology, and counts in the rat, rabbit, and dog." Reprod. Toxicology Special Article (A Consensus Report) 10(3): 237244.

Seleem, T.S.T., 2005. Some reproductive; productive and physiological aspects of purebred and crossbred Elander and New-Zealand White rabbits under Egyptian environmental conditions. In Proc: The 4th Inter. Con. on Rabbit Prod. in Hot Clim., Sharm El-Sheikh,Egypt,161-168.

Seleem T.S.T., H.M. Fayek, K.H. El-Kholy, S.M. Afifi, 2007. Rabbit productivity and reproductivity as influenced by prebiotics in drinking water. In Proc: 4th World Poultry Conf. 27- 30 March, Sharm El- Sheikh, Egypt, 603-627.

Sneath, P. H. A. and R. R. Sokal, 1973. Numerical Taxonomy. W. H. Freeman, San Francisco.

Snedecor G.W. and W.G. Cochran, 1967. Statistical Methods. 2nd Ed. Iowa State Univ. Press, Ames, Iowa, USA.

SPSS, 2004. Spss Advanced Model 15.0. South Wacker Drive, Chicago, 333 PP.

Tharwat, E. E. 1990. "Some physiological studies on pituitary-gonadal axis." Ph. D. Thesis, Ain shams Univ., Cairo-Egypt.

Vicente J.S., M.R. Viudes de Castro, R. Lavara, F. Lavara, 2000. Effect of male line on prolificacy from does inseminated with low sperm doses. In Proc: 7th World Rabbit Congress, vol. A. Valencia, Spain,1273-1277.

Watson P.F., 1975. Use of Giemsa stain to detect changes in acrosomes of frozen ram spermatozoa. Vet. Res. 97, 12-15.

\footnotetext{
صفات جودة السائل المنوى وأنماط بروتينات بلازما السائل المنوي لمختلف ذكور الأرانب المصرية محمد رضا عانوس'، عصمت بكرى عبدالله'، عاصم عبده متولى'، عادل عبدالعزيز البدوى '

ـ قـم الإنتاج الحيوانى ، كلية الزراعة جامعة عين شمس ، شبرا الخيمة ، القاهرة ، مصر، بــ معهد بحوث الإنتاج الحيوانى ، مركز البحوث

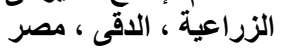

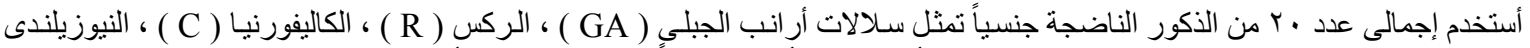

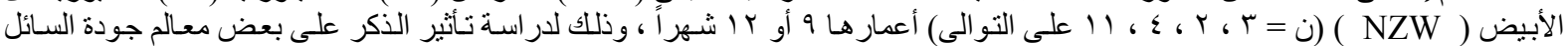

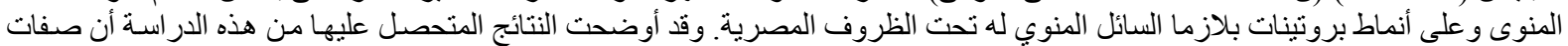

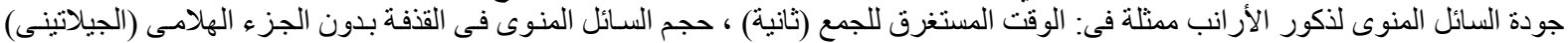

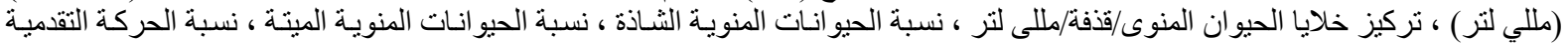

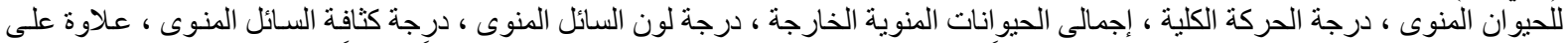

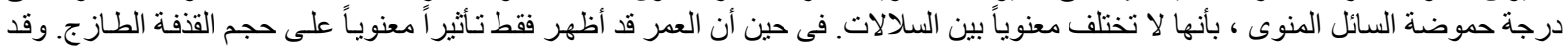

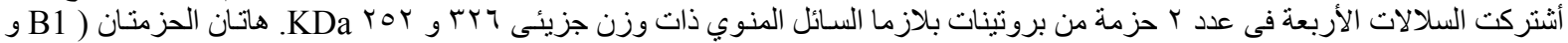

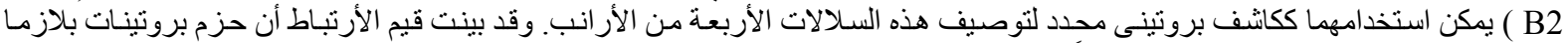

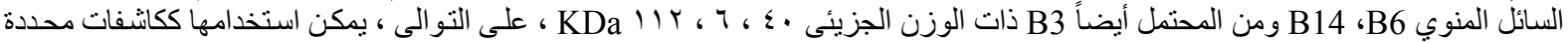

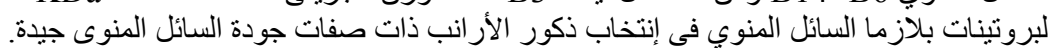

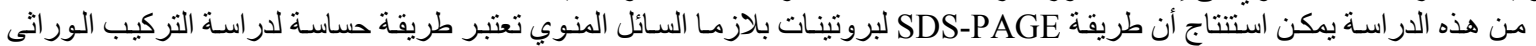

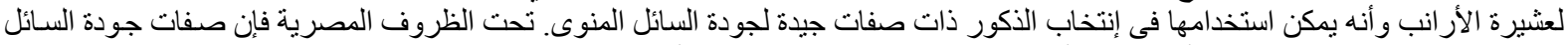
المنوى لذكور سلالة النيوزيلندى الأبيض تبدو أقل جودة من تللك لذكور السلالتين الأخرتين المستوردة التئ.
} 